\section{Influence of Bisphosphonates on the Behavior of Osteoblasts Seeded Onto Titanium Discs}

Fernanda G. Basso ${ }^{1} \mathbb{D}$, Taisa N. Pansani ${ }^{2}$ (D), Lais M. Cardoso ${ }^{2} \mathbb{D}$, Josimeri Hebling $^{2}$ (D), Rodrigo Paes Vila Real ${ }^{1}$ (D), Carlos Alberto de Souza Costa ${ }^{2}$ (i)
'School of Dentistry, UNAERP Universidade de Ribeirão Preto, Ribeirão Preto, SP, Brazil ${ }^{2}$ Araraquara School of Dentistry, UNESP - Universidade Estadual Paulista, Araraquara, SP, Brazil

Correspondence: Fernanda Gonçalves Basso, Avenida Costábile Romano, 2201, 14096-900 Ribeirão Preto, SP, Brasil. Tel: +55-16-3603-6780. e-mail: fergbasso@gmail.com

\begin{abstract}
Among other factors, types of bisphosphonates and treatment regimens seem to be strongly associated with the success or failure of installation of osseointegrated implants. This study investigated the influence of two bisphosphonates, sodium alendronate (SA) and zoledronic acid (ZA), on the metabolism of osteoblasts. Human osteoblasts (Saos-2) were seeded onto machined or acid-treated titanium discs previously placed on 24-well plates in complete culture medium. After $24 \mathrm{~h}$, cells were exposed to bisphosphonates at $0.5,1$ or $5 \mu \mathrm{M}$ for $24 \mathrm{~h}, 48 \mathrm{~h}$ or 7 days. The effects of SA and ZA on osteoblasts were assessed based on the adhesion of these cells to the titanium surfaces by direct fluorescence, cell viability, total protein and collagen synthesis. Alkaline phosphatase activity and mineral nodule deposition by these cells were also evaluated. Data were evaluated by ANOVA and Tukey tests $(\alpha=0.05)$. Decreased adhesion of cells to the titanium discs was observed when exposed to both bisphosphonates; however, this lack of cell adhesion was more evident for ZA-treated cells. In addition, the exposure of osteoblasts to ZA decreased the viability, ALP activity and mineral nodule deposition, which may be related to poor osseointegration after implant installation.
\end{abstract}

Key Words: bisphosphonates, implantology, osseointegration, osteoblasts.

\section{Introduction}

Several drugs have been related to the development of maxillofacial osteonecrotic lesions $(1,2)$, such as antiresorptive drugs and antiangiogenic drugs. For this reason, this condition is currently described as medication-related osteonecrosis of the jaw (MRONJ) (1).

Among the anti-resorptive drugs, bisphosphonates have been extensively related to the development of this pathological condition $(1,3,4)$. These drugs are pyrophosphate analogues and present a high affinity for hydroxyapatite crystals, where approximately $80 \%$ accumulate after intake. Bisphosphonates are recommended for patients with underlying diseases that lead to unbalanced bone remodeling, such as osteoporosis and bone metastatic tumors (5).

After a traumatic or inflammatory condition, these drugs are released from bone for months or even years. Once released, bisphosphonates act by inhibiting the maturation of pre-osteoclasts into osteoclasts, through the RANK-RANKL pathway, and also by inducing the apoptosis of osteoclasts via the mevalonate pathway (6). However, these drugs show poor specificity and may also harvest other cell lines, such as osteoblasts (6).

Previous studies have demonstrated that the inhibitory effects of bisphosphonates on osteoblasts could be related to the development of bisphosphonate-related osteonecrosis of the jaws (7-9). The incidence of osteonecrotic areas in the oral cavity following bisphosphonate treatment is related to the type of drug, frequency, dose and method of administration (7-9). For this reason, high-potency bisphosphonates such as zoledronate and the intravenous administration of such drugs are listed as being more predictive of the development of osteonecrosis (7-9). Among local factors, inflammatory and infectious conditions including trauma are also listed as predisposal factors for the development of areas of osteonecrotic bone (8).

Due to the risk of development of osteonecrosis, the insertion of oral osseointegrated implants for patients under bisphosphonate treatment remains controversial $(1,2,10)$, with different outcomes being described in the current literature $(1,2,10)$. Among other factors, these variable outcomes seem to be related to the type and concentration of bisphosphonate used. However, the cellular and molecular events associated with the clinical success or failure of the insertion of dental implants for these patients have not been completely elucidated.

This study aimed to determine the roles of different concentrations of two bisphosphonates on the behavior of human osteoblasts seeded onto titanium surfaces.

\section{Material and Methods} Titanium Discs

Commercially pure titanium discs (grade IV, $13 \times 1.5$ 
$\mathrm{mm}$ ) were ground wet with 400-, 600- and 1200-grit silicon carbide paper (3M do Brasil, Sumaré, SP, Brazil) to obtain standardized machined surfaces. For acid-treated surfaces, discs were treated with 10\% hypochloric acid in deionized water. The surface roughness of both machined and acidtreated discs was evaluated by confocal microscopy (ULS 4000, Olympus Corporation, Center Valley, PA, USA). Then, discs were ultrasonically cleaned in 95\% ethanol and deionized water and sterilized in an autoclave.

\section{Cell Culture and Bisphosphonate Treatment}

Before cells were seeded, titanium discs were allocated into wells of a 24-well cell culture plate. Then, $1 \mathrm{~mL}$ of Dulbecco's Modified Culture Medium (DMEM, Gibco, Carlsbad, CA, USA), containing 1\% of antibiotic solution (PenStrep, Gibco) and supplemented with 10\% of fetal bovine serum (FBS), was applied to each well. Human osteoblasts (SaOs-2-ATCC \#HTB85) were seeded onto each disc $\left(5 \times 10^{4}\right.$ cells/disc).

After $24 \mathrm{~h}$, the culture medium was replaced by fresh serum-free DMEM containing different concentrations of each bisphosphonate, sodium alendronate (SA) or zoledronic acid (ZA) $(0,0.5 \mu \mathrm{M}, 1 \mu \mathrm{M}$ or $5 \mu \mathrm{M})$. This culture medium was supplemented with betaglycerophosphate and ascorbic acid (osteogenic medium) (Sigma-Aldrich, St. Louis, MO, USA). The doses of bisphosphonates were selected according to a study of Schepper et al. (11), which comparatively demonstrated the concentrations of bisphosphonates found in the oral cavity of patients under treatment with these drugs. Also, these concentrations were already evaluated in previous investigations of the group.

Cells were treated for $48 \mathrm{~h}$ or 7 days, according to the selected protocols, and culture medium containing the drugs was replaced every $48 \mathrm{~h}$.

\section{Cell Adhesion - Fluorescence}

The adhesion of osteoblasts was also qualitatively and quantitatively assessed by fluorescence, with a cytoskeleton marker used for actin (Actin Probe, Molecular Probes, Carlsbad, CA, USA). Cells were fixed in $4 \%$ paraformaldehyde, subjected to permeabilization with $0.1 \%$ triton- $x$ and incubated with the actin probe for $30 \mathrm{~min}$ in the absence of light. Nuclei were identified by incubation with a DNA intercalant (Hoechst - 1:5000) for $15 \mathrm{~min}$. Then, samples were analyzed by fluorescence microscopy (EVOS FL Image System, Thermo Fisher Scientific, Waltham, MA, USA).

\section{Cell Viability}

The effects of bisphosphonates on osteoblasts were determined by the MTT assay, which provides the detection of the activity of a mitochondrial enzyme (succinic dehydrogenase), which corresponds to the metabolic cell rate. Cells were incubated with MTT solution $(5 \mathrm{mg} / \mathrm{mL}$ in PBS) diluted at 10\% in serum-free culture medium for 4 $\mathrm{h}$ at $37^{\circ} \mathrm{C}$ and $5 \% \mathrm{CO}_{2}$. After this period, $200-\mu \mathrm{L}$ aliquots were transferred to a 96-well plate, and absorbance was determined by spectrophotometry at $570 \mathrm{~nm}$ (Synergy H1, BioTek, Winooski, VT, USA).

\section{Total Protein Production and ALP Activity}

Total protein production was determined by the Lowry colorimetric method and analyzed by spectrophotometry $(655 \mathrm{~nm})$. The protein production was used to determine the metabolism of cells as well as to normalize the ALP activity for each sample. ALP activity was assessed by endpoint assay based on the breakage of thymolphthalein and was evaluated by absorbance rate at $540 \mathrm{~nm}$ (Synergy H1).

\section{Mineral Nodule Formation}

The deposition of mineral nodules was evaluated by the Alizarin Red Method. Cells were fixed in $70 \%$ ethanol at $4{ }^{\circ} \mathrm{C}$ for $1 \mathrm{~h}$, after which mineral nodules were detected by alizarin red staining $(40 \mathrm{mM})$ for 20 min under agitation. Then, samples were washed in deionized water, and, to facilitate quantitative analysis of mineral deposition, nodules were dissolved in cetylpyridinium (10\%) for 15 min under agitation. After this procedure, a purple solution was obtained and subjected to absorbance analysis at 562 nm (Synergy H1).

\section{Collagen Synthesis}

Soluble collagen produced by osteoblasts was evaluated by the Sirius Red method, using the culture medium that remained in contact with cells (culture medium from all periods was stored at $-20{ }^{\circ} \mathrm{C}$ ). A $500-\mu \mathrm{L}$ quantity of the culture medium of each sample was transferred to a $1.5-\mathrm{mL}$ tube followed by the addition of Direct Red reagent at 1\%. Samples were incubated for $1 \mathrm{~h}$ at room temperature under agitation (400 rpm; Thermomixer, Eppendorf, Hamburg, Germany). Then, samples were centrifuged at $12,000 \mathrm{rpm}$ for $10 \mathrm{~min}$. The supernatant fraction was discarded, and pellets were washed in hydrochloric acid (0.1 M) followed by centrifugation. After supernatant was discarded, pellets were re-suspended in sodium hydroxide $(0.5 \mathrm{M})$ and were aliquoted to 96 -well plates. Absorbance was determined by spectrophotometry at $555 \mathrm{~nm}$ (Synergy H1).

\section{Statistical Analysis}

The resulting data presented normal distribution (Shapiro-Wilk test, $\mathrm{p}<0.05$ ); therefore, parametric tests (ANOVA and Tukey) were applied for statistical analysis. All statistical inferences were based on 5\% as significant. 


\section{Results}

Cell viability was not significantly affected when osteoblasts were exposed to bisphosphonates at all concentrations for 24 and $48 \mathrm{~h}$ ( $p>0.05)$ (Fig. 1A, 1B). However, after a 7-day period of continuous treatment, cells seeded onto titanium discs treated with ZA showed diminished viability for all concentrations $(p<0.05)$ (Fig. $1 \mathrm{C})$. The cytotoxicity was higher as ZA concentrations were increased regardless of the type of titanium surface (machined or acid-treated discs) $(p<0.05)$. For SA-treated cells, no significant effect on viability of human osteoblasts was observed ( $p>0.05$ ). In contrast, at the 7-day period, cells seeded onto acid-treated titanium surfaces showed higher viability after SA treatment $(p<0.05)$.

The adherence of osteoblasts to titanium surfaces was negatively affected by ZA at all concentrations used; however, the adhesion of SA-treated cells was hampered only at the highest concentration tested, as observed for the qualitative analysis by fluorescence (Fig. 2).

Despite decreased cell viability, collagen synthesis was not affected by treatment with both bisphosphonates ( $p>0.05$ ) (Fig. 3A). Decreased total protein synthesis (Fig. 3B) and ALP activity (Fig. 3C) were observed for ZA-treated $\vec{z}$ cells seeded onto both types of titanium discs $(p<0.05)$, $\stackrel{ \pm}{ \pm}$ in a concentration-dependent way. These cell activities were also negatively affected by SA, mainly at higher concentrations $(p<0.05)$.

Decreased mineral nodule formation was observed for osteoblasts exposed for 7 days to both bisphosphonates $(p<0.05)$; this effect was more intense as the concentrations of these drugs increased (Fig. 3D). Significant differences were observed when cells were seeded onto machined and acid-treated discs $(p<0.05)$.

Overall, for cells treated with the selected bisphosphonates, rougher surfaces did not provide a better environment for cell attachment or phenotype.

\section{Discussion}

The insertion of oral implants for patients under bisphosphonate treatment has led to distinct clinical outcomes $(1,2,10)$. Previous clinical reports and reviews demonstrated that these clinical procedures may result in successful prosthetic rehabilitation; however, some patients have experienced implant failure and development of osteonecrotic areas on maxillary bones $(1,2,10)$. The distinct outcomes may be related to the patients' underlying disease requiring bisphosphonate treatment, while this factor may be directly related to the type of bisphosphonate, the method of administration and doses $(12,13)$.

It has been shown that, after intake, bisphosphonates adhere to hydroxyapatite crystals of mineral tissues, and their release can be triggered by a traumatic, inflammatory or neoplastic condition that results in bone resorption (14). Once released, these drugs mainly inhibit osteoclast maturation and induce apoptosis of these cells; however, several studies have demonstrated that these drugs also show cytotoxic and cytopathic effects on osteoblasts (15-18).

The long-term success of implantation depends on the effective osseointegration of titanium implants $(19,20)$. The process of osseointegration itself is directly related to the adhesion of osteoblasts to titanium surfaces as well as the

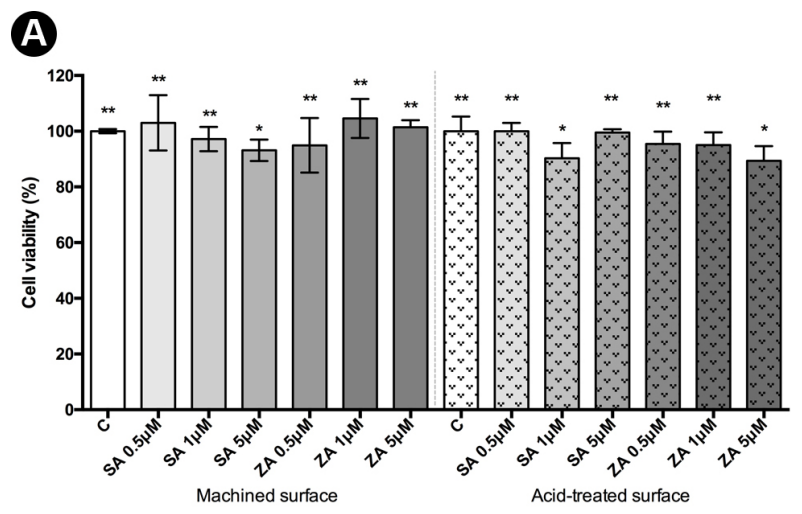

B

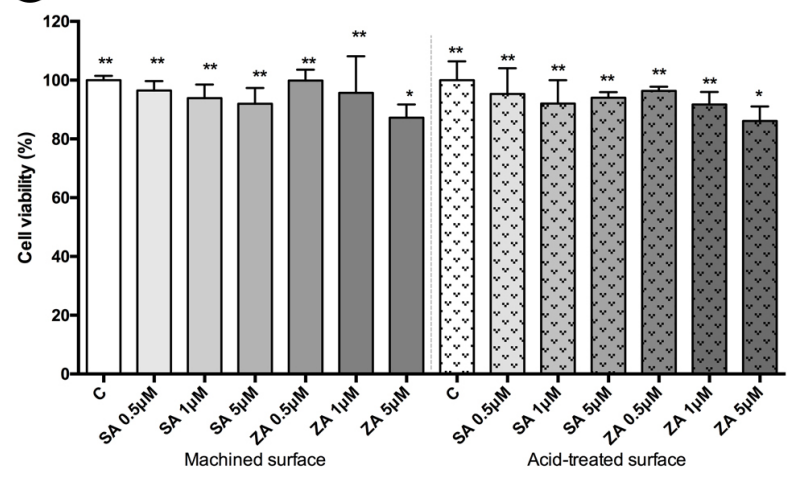

C

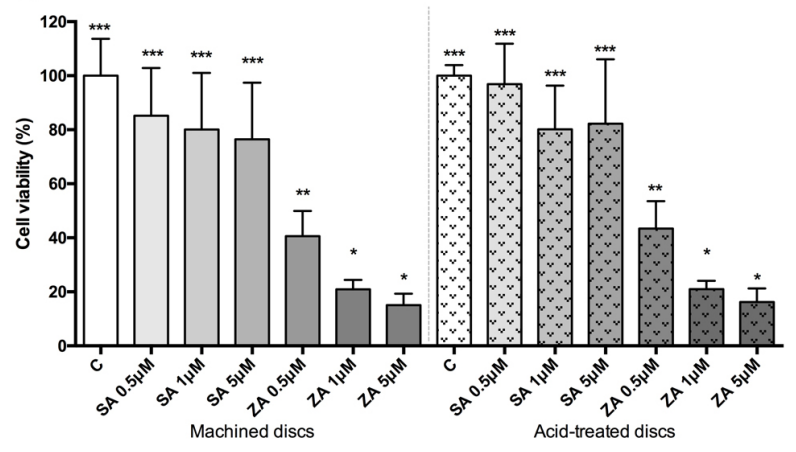

Figure 1. Viability of osteoblasts seeded onto titanium discs and treated with bisphosphonates at different concentrations for $24 \mathrm{~h}$ (A), $48 \mathrm{~h}(\mathrm{~B})$ and 7 days (C). $\mathrm{n}=6$. Bars indicate mean values and standard deviation. Groups indicated by different symbols are statistically significantly different (Tukey, $\mathrm{p}<0.05$ ). 
synthesis and mineralization of a collagen-rich matrix by these cells (21). Therefore, the adhesion and metabolism of osteoblasts to these surfaces, as well as the synthesis of collagen matrix and its mineralization, are the main cellular events during this process. Hence, the evaluation of these cellular and molecular events is crucial to determination of the influence of bisphosphonates on oral implantology.

The present investigation evaluated the influence of two bisphosphonates and their concentrations on the adhesion, viability and metabolism of osteoblasts seeded onto titanium surfaces. Results demonstrated that, for
SA, which is a moderately potent orally administered bisphosphonate, slightly negative effects were observed in the cultured cells only when the higher concentration of this drug was used. Similar results had previously been demonstrated for SA at low concentrations; however, that may not represent the local concentrations of these drugs after months or years of intake (22). The maintenance of osteoblast viability and metabolism after SA treatment may suggest that the patients under treatment with this type of bisphosphonate may not experience negative outcomes regarding osseointegration after insertion of oral implants.
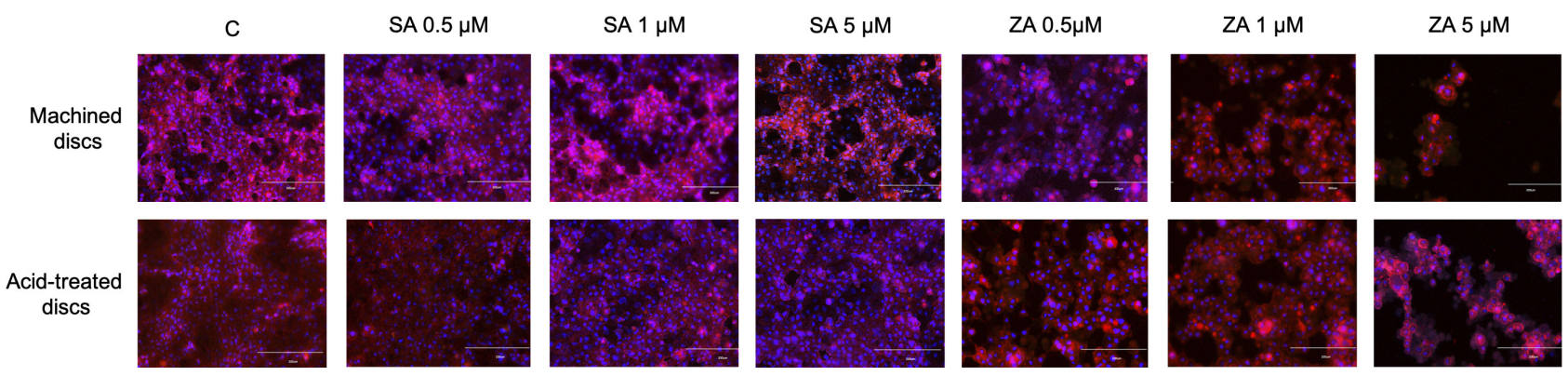

Figure 2. Osteoblasts adhered to the machined and acid-treated titanium surfaces after a 7-day period of treatment with bisphosphonates at different concentrations.

A

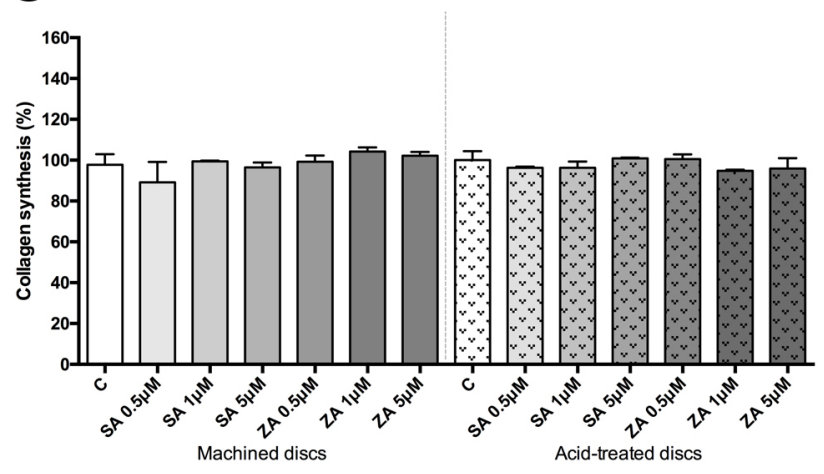

C

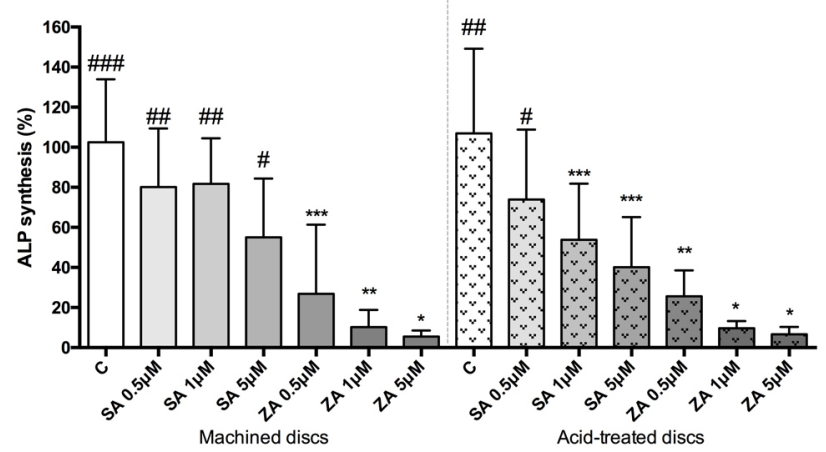

B

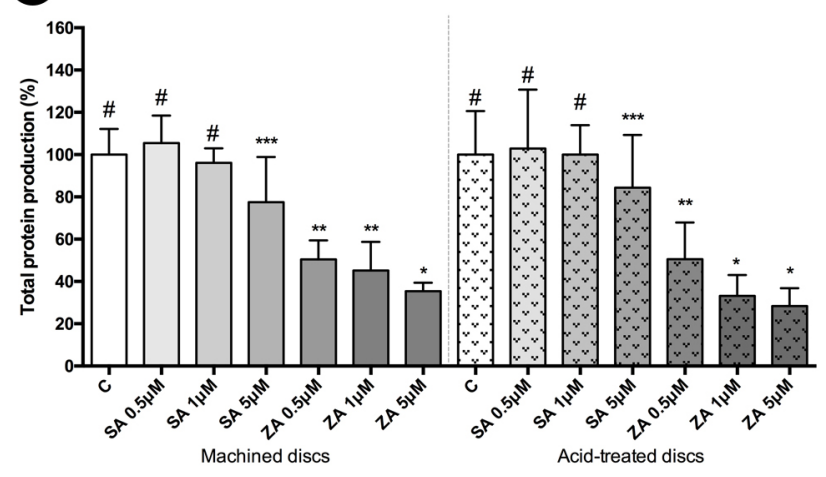

D

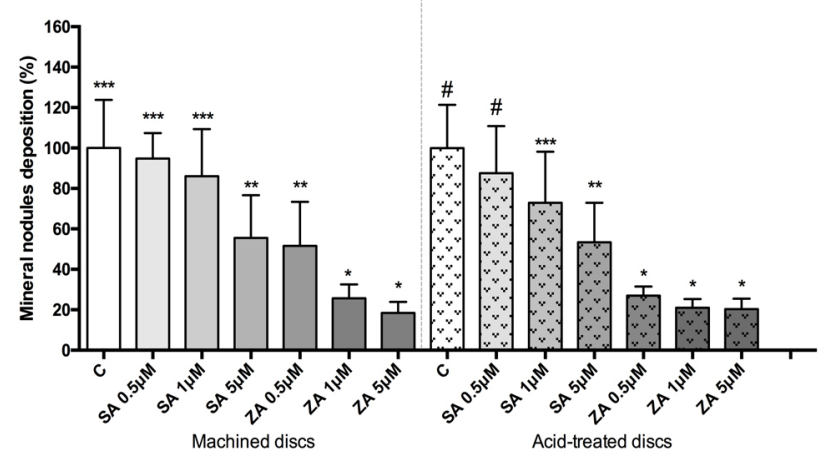

Figure 3. Total protein production (A), collagen synthesis (B), ALP activity (C) and mineral nodule formation (D) by osteoblasts seeded onto titanium discs and treated with bisphosphonates at different concentrations for 7 days. $\mathrm{n}=6$. Bars indicate mean values and standard deviation. Groups indicated by different symbols are statistically significantly different (Tukey, $\mathrm{p}<0.05$ ). 
Indeed, patients undergoing SA treatment show few adverse effects after the insertion of oral implants (1). Still, the treatment protocol may directly affect the local release of this drug, so these patients must be handled carefully.

Conversely, few osteoblasts exposed to ZA adhered to the titanium surfaces, and these cells also showed decreased viability and metabolism, demonstrated by ALP activity and mineral nodule deposition, which are in vitro indicators of the mineralization capacity of these cells. The concentrations of bisphosphonates applied during this investigation were selected according to previous investigations $(11,17,18)$. Therefore, we suggest that the presence of high concentrations of this drug may lead to poor osseointegration. Again, since the adherence and release of ZA can be influenced by several factors, the concentrations selected for this study may underestimate the concentration at the time of oral implant insertion and the effects of this drug on peri-implant tissues.

These results show a high similarity to the outcomes observed for in vivo and clinical studies, where patients under ZA treatment were the most affected by adverse effects following implant insertion, such as peri-implantitis and osteonecrotic areas $(1,2)$.

In terms of surface topography, this investigation demonstrated that osteoblasts showed higher cell adhesion and metabolism when seeded onto the acid-treated titanium discs. Similar results have already been described in previous studies, in which the authors demonstrated that these cells exhibited higher viability and metabolic activity when seeded onto rough titanium surfaces compared with plain surfaces (23).

However, in the present investigation, the osteoblasts demonstrated the same response to bisphosphonate treatment, suggesting that the implant surface may not play a fundamental role in the insertion of oral implants in patients under treatment with these drugs. These results also demonstrate that the use of acid-treated surfaces may not be a suitable strategy to improve osseointegration for patients receiving bisphosphonate treatment.

Resulted data highlight the negative influence of zoledronic acid on osteoblasts seeded in this condition, demonstrated by decreased cell adhesion and metabolism when cells were exposed to this drug. Considering the limitations of this study, these effects may be associated to the negative outcomes observed for the installation of oral implants in patients with present or previous history of treatment with zoledronic acid. Thus, these results also bring to light the necessity of treatment strategies that can improve the interaction and metabolism of bone cells and also improve the sensitivity of these cells to the contact with bisphosphonates, mainly zoledronic acid.

\section{Resumo}

Entre outros fatores, os tipos de bisfosfonatos bem como os regimes de tratamento parecem estar diretamente associados com o sucesso ou falhas na instalação de implantes osseointegrados. Este estudo avaliou a influência de dois bisfosfonatos, o alendronato de sódio (AS) e o ácido zoledrônico (AZ), no metabolismo de osteoblastos. Osteoblastos humanos (Saos-2) foram cultivados sobre discos de titânio polidos ou submetidos a tratamento ácido superficial, previamente alocados em placas de 24 compartimentos, utilizando meio de cultura completo. Após 24 horas, as células foram expostas aos bisfosfonatos, nas concentrações de 0,5 , 1 ou $5 \mu \mathrm{M}$, por $24 \mathrm{~h}, 48 \mathrm{~h}$, ou 7 dias. Os efeitos do AZ e AZ sobre os osteoblastos foram determinados considerando a adesão destas células às superfícies de titânio, por meio de fluorescência direta, a viabilidade celular, produção de proteína total e sintese de colágeno. A atividade de fosfatase alcalina e a deposição de nódulos mineralizados também foram avaliadas. Os dados foram analisados por meio do teste ANOVA complementado por Tukey $(\mathbb{Q}=0.05)$. Menor adesão dos osteoblastos foi observada quando estas células foram expostas a ambos os bisfosfonatos, porém, esta falha na adesão foi mais evidente para as células tratadas com AZ. Além disso, a exposição dos osteoblastos ao AZ também resultou em diminuição da viabilidade, atividade de ALP e deposição de nódulos mineralizados, o que pode estar relacionado a uma pobre osseointegração após a instalação do implante.

\section{Acknowledgements}

The authors acknowledge the Conselho Nacional de Desenvolvimento Científico and Tecnológico - CNPq (grants: \#442637/2014-4; 1577792015-7; 302108/2019-0) and São Paulo Research Foundation (FAPESP \# 2018/11211-6) for the financial support.

\section{References}

1. Guazzo R, Sbricoli L, Ricci S, Bressan E, Piattelli A, laculli F. Medicationrelated osteonecrosis of the jaw and dental implants failure: a systematic review. J Oral Implantol 2017;43:51-57.

2. Walter C, Al-Nawas B, Wolff T, Schiegnitz E, Grötz, KA. Dental implants in patients treated with antiresorptive medication - a systematic literature review. Int J Impl Dent 2016;2:9-23.

3. Marx RE. Pamidronate (Aredia) and zoledronate (Zometa) induced avascular necrosis of the jaws: a growing epidemic. J Oral Maxillofac Surg 2003;61:1115-1117.

4. Ruggiero SL, Dodson TB, Fantasia J, Goodday R, Agaloo T, Mehrotra, B et al. American Association of Oral and Maxillofacial Surgeons position paper on medication-related osteonecrosis of the jaw - 2014 update. J Oral Maxillofac Surg 2014;72:1938-1956.

5. Rodan GA, Martin TJ. Therapeutic approaches to bone diseases. Science 2000;289:1508-1514.

6. Maruotti N, Corrado A, Neve A, Cantatore FP. Bisphosphonates: effects on osteoblasts. Eur J Clin Pharmacol 2012;68:1013-1018.

7. Fung $P L$, Nicoletti $P$, Shen $Y$, Porter $S$, Fedele $S$. Pharmacogenetics of bisphosphonate-associated osteonecrosis of the jaw. Oral Maxillofac Surg Clin N Am, 2015;27:537-546.

8. Otto S, Pautke C, Opelz C, Westphal I, Drosse I, Schwager J et al. Osteonecrosis of the jaw: effect of bisphosphonate type, local concentration, and acidic milieu on the pathomechanism. J Oral Maxillofac Surg 2010;68:2837-2845.

9. Shannon J, Shannon J, Modelevsky S, Grippo AA. Bisphosphonates and osteonecrosis of the jaw. J Am Geriatr Soc 2011;59:2350-2355.

10. Ata-Ali J, Ata-Ali F, Peñarrocha-Oltra D, Galindo-Moreno P. What is the impact of bisphosphonate therapy upon dental implant survival? A systematic review and meta-analysis. Clin Oral Impl Res 2016;27:38-46.

11. Schepper MA, Badros A, Salama AR, Warburton G, Cullen KJ, Weikel DS et al. A novel bioassay model to determine clinically significant bisphosphonate levels. Support Care Cancer 2009;17:1553-1557.

12. Assael LA. Oral bisphosphonates as a cause of bisphosphonate-related osteonecrosis of the jaws: clinical findings, assessment of risks, and 
preventive strategies. J Oral Maxillofac Surg 2009:67:35-43.

13. Madrid C, Sanz M. What impact do systemically administered bisphosphonates have on oral implant therapy? A systematic review. Clin Oral Impl Res 2009;20:87-95.

14. Russell RG. Bisphosphonates: the first 40 years. Bone 2011;49:2-19.

15. Idris Al, Rojas J, Greis IR, van't Hof RJ, Ralston SH. Aminobisphosphonates cause osteoblast apoptosis and inhibit bone nodule formation in vitro. Calcified Tissue Int 2008;82:191-201.

16. Orriss IR, Key ML, Colston KW, Arnett TR. Inhibition of osteoblast function in vitro by aminobisphosphonates. J Cell Biochem 2009;106:109-118.

17. Basso FG, Turrioni APS, Hebling J, de Souza Costa CA. Zoledronic acid inhibits human osteoblast activities. Gerontol 2013;59:534-541.

18. Basso FG, Turrioni APS, Soares DG, Bagnato VS, Hebling J, de Souza Costa CA. Low-level laser therapy for osteonecrotic lesions: effects on osteoblasts treated with zoledronic acid. Support Care Cancer 2014;22:2741-2748.
19. Joos U, Wiesmann HP, Szuwart T, Meyer U. Mineralization at the interface of implants. Int J Oral Maxillofac Surg 2006;35:783-790.

20. Chang $P$, Lang NP, Giannobile WV. Evaluation of functional dynamics during osseointegration and regeneration associated with oral implants: a review. Clin Oral Impl Res 2010;21:1-12.

21. Berglundh T, Abrahamsson I, Lang NP, Lindhe. De novo alveolar bone formation adjacent to endosseous implants. Clin Oral Impl Res 2003;14:616-620.

22. Alqhtani NR, Logan NJ, Meghji S, Leeson R, Brett PM. Low dose effect of bisphosphonates on hMSCs osteogenic response to titanium surface in vitro. Bone Rep 2017;6:64-69.

23. Mariscal-Muñoz E, Costa CA, Tavares HS, Bianchi J, Hebling J, Machado $\mathrm{JP}$ et al. Osteoblast differentiation is enhanced by a nano-to-micro hybrid titanium surface created by Yb:YAG laser irradiation. Clin Oral Invest 2016;20:503-511. 